\title{
STATUS VITAMIN D TERKINI ANAK INDONESIA USIA 2,0-12,9 TAHUN
}

\author{
Fitrah Ernawati ${ }^{12}$, Basuki Budiman ${ }^{12}$ \\ ${ }^{1}$ Tim SEANUTS, Persatuan Ahli Gizi Indonesia (PERSAGI) \\ 2Peneliti Pusat TTKEK, Badan Litbang Kesehatan, Jakarta \\ fitrahernawati@yahoo.com
}

\begin{abstract}
ABSTRAK
Masalah kurang vitamin D merupakan masalah gizi terbaru yang menjadi perhatian saat ini. Berbagai studi di luar negeri, baik di negara sub-tropis maupun tropis, menunjukkan prevalensi yang cukup tinggi. Di Indonesia belum banyak laporan tentang status vitamin D pada anak dan kelompok lain. Studi ini bertujuan mengetahui status vitamin $D$ pada anak umur 2,0-12,9 tahun di Indonesia dan faktor yang berperan. Analisis menggunakan data anak usia 2,0 - 12,9 tahun dari South East Asian Nutrition Survey (SEANUTS) yang dikumpulkan tahun 2011. Desain penelitian adalah potong lintang di 48 Kabupaten di Indonesia. Pengukuran kadar 25-hydroxyvitamin D [25(OH)D] menggunakan enzym immuno assay. Analisis data menggunakan ANOVA and korelasi. Hasil penelitian menunjukkan rerata kadar vitamin D anak umur 2,0-12,9 tahun 52.6 $\pm 0,7 \mathrm{nmol} / \mathrm{L}$. Prevalensi deficiency vitamin $\mathrm{D}$ (serum 25(OH)D $<25 \mathrm{nmol} / \mathrm{L}$ ), insufficiecy (25-49 $\mathrm{nmol} / \mathrm{L})$, inadequate $(50-74 \mathrm{nmol} / \mathrm{L})$, dan desirable $(\geq 75 \mathrm{nmol} / \mathrm{L})$ berturut-turut 0 persen, 45,1 persen, 49,3 persen, dan 5,6 persen. Kadar vitamin $D$ lebih tinggi pada anak lelaki $(54,7 \pm 0,9 \mathrm{nmol} / \mathrm{L})$ dibanding perempuan $(49,9 \pm 1,0 \mathrm{nmol} / \mathrm{L})$. Dijumpai hubungan positif antara lama melakukan aktifitas diluar rumah dengan kadar vitamin $D(r=0,164, p=0,012)$. Kadar vitamin $D$-pada anak kelompok umur 2,0-2,9 tahun yaitu 54,0 $2,3 \mathrm{nmol} / \mathrm{l}$, sedangkan pada anak kelompok umur 9,0-12,9 tahun yaitu 50,3 $\pm 1,4 \mathrm{nmol} / \mathrm{l}$. Kadar vitamin $D$ anak yang tinggal di kota $(52,5 \mathrm{nmol} / \mathrm{l})$ tidak berbeda dengan anak yang tinggal di desa $(52,6 \mathrm{nmol} / \mathrm{l})$. Hasil penelitian menunjukkan bahwa status vitamin D pada anak usia sekolah perlu mendapat perhatian.
\end{abstract}

Kata kunci: status vitamin D, anak usia 1,0-12,9 tahun, aktifitas di luar rumah

\section{ABSTRACT}

\section{CURRENT STATUS OF VITAMIN D IN INDONESIAN CHILDREN 2,0-12,9 YEARS OLD}

Vitamin $D$ deficiency is an emerging nutritional problem. Studies in subtropical and tropical countries have shown high prevalence of vitamin D deficiency. However, the vitamin D status of school children and other groups in indonesia is still underreported. The objective of this study is to assess vitamin D status and its associated factors in children aged 2.0-12.9 year. The data used for the analysis is secondary data of children 2.0-12.9 year old taken from the cross-sectional study of South East Asian Nutrition Survey (SEANUTS) conducted in 48 districts in 2011. Serum 25-hydroxyvitamin D [25(OH)D] level was measured using enzyme immuno assay. Statistical analysis of data used ANOVA and Correlation test. The results showed that the mean serum 25(OH)D was $52.6 \pm 0,7 \mathrm{nmol} / \mathrm{L}$. The prevalence of vitamin $\mathrm{D}$ deficiency (serum 25(OH)D < $25 \mathrm{nmol} / \mathrm{L})$, insufficiency (25-49 nmol/L), inadequate (50-74 nmol/L), and desirable $(\geq 75$ $\mathrm{nmol} / \mathrm{L}$ ) were $0 \%, 45.1$ per cent, 49.3 per cent, dan 5.6 per cent ,respectively. Vitamin $D$ level in boys $(54,0 \pm 2,3 \mathrm{nmol} / \mathrm{L})$ was higher than in girls $(49.9 \pm 1.0 \mathrm{nmol} / \mathrm{L})$. There was an association between vitamin $D$ levels with outdoors activity $(r=0.164, p=0.012)$. Mean vitamin $D$ level in children aged 2,0-2,9 years was 54.0 $\pm 2.3 \mathrm{nmol} / \mathrm{l}$, while in children aged $\mathbf{9 . 0 - 1 2 . 9}$ years was $50,3 \pm 1,4 \mathrm{nmol} / \mathrm{l}$. There was no significant difference of vitamin $D$ level between urban children $(52.5 \mathrm{nmol} / \mathrm{L})$ and rural children $(52.6 \mathrm{nmol} / \mathrm{L})$. The study draws our attention to vitamin D status in children 2.0-12.9 years old..

Keywords: vitamin D status, children aged 1,0-12,9 years, outdoors activity

\section{PENDAHULUAN}

$\mathrm{M}$ asalah kurang vitamin $D$ menjadi masalah gizi yang hangat dibicarakan dan mendapat perhatian dari beberapa negara di dunia saat ini. Berbagai studi di luar negeri baik di negara sub-tropis maupun tropis menunjukkan prevalensi kekurangan vitamin $\mathrm{D}$ cukup tinggi1. Di Indonesia belum banyak laporan tentang status vitamin $D$ pada anak maupun kelompok lainnya. Kekurangan vitamin D menunjukkan bahwa tubuh kekurangan 
vitamin $D$ dan sudah memberikan tanda klinis seperti rickets pada anak dan osteomalasia pada orang dewasa. Meningkatnya prevalensi deficiency atau insufficieny vitamin $D$ antara lain karena rendahnya asupan sumber vitamin $D$, kecenderungan mengurangi bahan makanan tinggi lemak yang berakibat rendahnya serapan vitamin $\mathrm{D}$, meningkatnya penggunaan tabir surya, dan kurang terpajannya sinar matahari2,3.

Klasifikasi status vitamin D sampai saat ini masih menjadi perdebatan. Pada artikel ini digunakan klasifikasi status vitamin $\mathrm{D}[25(\mathrm{OH}) \mathrm{D}]$ sebagai berikut deficiency vitamin $D$ apabila kadar vitamin $D$ serum $(25(\mathrm{OH}) \mathrm{D})<25 \mathrm{nmol} / \mathrm{L}$, insufficiecy bila kadar vitamin D antara 25-49 $\mathrm{nmol} / \mathrm{L}$, inadequate bila kadar vitamin $\mathrm{D}$ antara 50-74 nmol/L, dan dinyatakan status desirable bila kadar vitamin $D \geq 75 \mathrm{nmol} / \mathrm{L}(4)$.

Serum 25-hydroxyvitamin D [25(OH)D] adalah vitamin $D$ yang paling banyak di temukan di dalam sirkulasi darah dan mempunyai masa hidup yang panjang. Penentuan status vitamin $D$ pada manusia yang paling banyak digunakan adalah dengan pengukuran kadar $25(\mathrm{OH}) \mathrm{D}$ dalam serum. Kadar $25(\mathrm{OH}) \mathrm{D}$ di dalam serum mencerminkan total asupan vitamin $\mathrm{D}$ dari sintesa vitamin $\mathrm{D}$ di dalam tubuh dan juga berasal dari makanan, baik vitamin D2 atau Vitamin D3. Dengan demikian, serum 25(OH)D dapat digunakan untuk menunjukkan seseorang mengalami defisiensi vitamin D, insufficient, dan hypovitaminosis atau cukup. Kadar vitamin D di dalam tubuh dipengaruhi oleh keterpaparan sinar ultraviolet' ${ }^{1}$. Sintesa vitamin D3 di kulit melibatkan dua tahapan yaitu perubahan photokimia 7-dehydrocholesterol menjadi previtamin D3, diikuti dengan isomerasi vitamin D3. Faktor yang mempengaruhi perubahan previtamin $D$ di kulit antara lain pigmentasi kulit dan intensitas paparan sinar ultraviolet ${ }^{2}$.

Vitamin $D$ dari kulit dan makanan di metabolisme di liver menjadi 25-hydroxyvitamin $D$ yang digunakan untuk menentukan status vitamin $D$ seseorang. 25-hydroxyvitamin $D$ ini kemudian dimetabolisme diginjal oleh enzim 25hydroxyvitamin D-1a-hydroxylase (CYP27B1) menjadi bentuk vitamin $D$ aktif yaitu 1,25dihydroxyvitamin D. Produksi 1,25dihydroxyvitamin $D$ ini diatur oleh kadar hormon parathyiroid dan kadar kalsium dan pospor serum. Produksi 1,25 $(\mathrm{OH}) 2 \mathrm{D}$ di ginjal dalam keadaan terkontrol seimbang, terutama oleh hormon parathyroid. Penurunan serum calcium menyebabkan peningkatan sekresi hormon parathyroid dari kelenjar parathyroid yang berperan untuk memobilisasi cadangan calcium dari tulang. Hormon Parathyroid juga membantu sintesa 1,25 $(\mathrm{OH}) 2 \mathrm{D}$ di ginjal yang menstimulasi mobilisasi calsium dari tulang dan usus. Hal ini sekarang diketahui bahwa 1,25 $(\mathrm{OH}) 2 \mathrm{D}$ dapat juga diproduksi secara lokal oleh macrofag yang teraktivasi, beberapa sel lymphoma dan kultur kulit serta sel tulang?2.

$\mathrm{Di}$ Indonesia masih sangat terbatas informasi tentang status vitamin $D$ baik pada anak maupun pada orang dewasa. Hasil Penelitian Soesanti $F($ 2013) menunjukkan bahwa 75,8 persen anak usia 7-12 tahun mempunyai kadar vitamin $D$ dengan kategori insufficient, dan 15 persen dengan kategori deficiency. Dari hasil penelitian yang sama menemukan hal yang berbeda dengan temuan penelitian ini bahwa status vitamin D tidak berhubungan dengan paparan sinar matahari $\left(x^{2}, P=0.143\right)^{9}$.

Dengan memperhatikan pentingnya peranan vitamin $D$ di dalam tubuh selain peranan sebagai stimulator penyerapan kalsium, maka artikel ini akan memaparkan bagaimana status vitamin $D$ anak Indonesia umur 1,0-12,9 tahun. Penelitian bertujuan menilai status vitamin $D$ pada anak umur 1,012,9 tahun di Indonesia dan faktor yang berhubungan dengan kadar vitamin $D$ anak.

\section{METODE PENELITIAN}

Penelitian ini merupakan bagian dari penelitian South East Asian Nutrition Survey (SEANUTS) yang dikumpulkan pada tahun 2011. Sampel penelitian adalah anak umur 2,0 tahun sampai 12,9 tahun. Desain penelitian adalah potong lintang yang mencakup 48 Kabupaten di Indonesia. Kriteria inklusi adalah sehat secara fisik dan klinis yang diperiksa oleh dokter. Orang tua anak mengijinkan anak diikutkan dalam penelitian. Jumlah anak seluruhnya 7211 , tetapi anak yang diperiksa darah vena nya sebanyak 2576 orang dan yang diperiksa vitamin D (25-hydroxyvitamin D [25(OH)D] adalah 349 anak. Pengukuran kadar [25(OH)D] dengan menggunakan enzim immuno assay.

Klasifikasi status vitamin D yang digunakan dalam artikel ini sebagai berikut deficiency 
vitamin D apabila kadar $[25(\mathrm{OH}) \mathrm{D}]<25 \mathrm{nmol} / \mathrm{L}$, insufficiency bila kadar [25(OH)D] antara 25-49 $\mathrm{nmol} / \mathrm{L}$, inadequate bila antara 50-74 $\mathrm{nmol} / \mathrm{L}$, dan dinyatakan status desirable bila $\geq 75$ $\mathrm{nmol} / \mathrm{L}^{4}$. Selanjutnya data dianalisis secara deskriptif dan anallitis dengan ANOVA and Korelasi.

\section{HASIL}

Tabel 1 menunjukkan bahwa proporsi umur partisipan penelitian menunjukkan bahwa sebagian besar partisipan $(41,8 \%)$ pada kelompok anak berumur 6,0-8,9 tahun, urutan kedua adalah kelompok umur 3,0-5,9 tahun sebesar 25 persen. Gambar 1 menunjukkan bahwa rerata kadar $[25(\mathrm{OH}) \mathrm{D}]$ anak kelompok umur 2,0-12,9 tahun yaitu $54,0 \pm 13,5 \mathrm{nmol} / \mathrm{L}$, umur $3,0-5,9$ tahun yaitu $54,8 \pm 14,6 \mathrm{nmol} / /$, umur $6,0-8,9$ th yaitu $52,1 \pm 11,1$, umur $9,0-12,9$ th yaitu $50,3 \pm 12,7$.

Sedangkan berdasarkan status vitamin $D$, tidak ditemukan partisipan yang mengalami kekurangan vitamin $D$, sebanyak 45,1 persen mengalami insufficient, dan 49,3 persen dengan status inadequate, sedangkan yang mempunyai kecukupan vitamin $D$ hanya 5,6 persen (Tabel 2).

Tabel 1

Karakteristik Partisipan

\begin{tabular}{lcc}
\hline Karakteristik & $\mathrm{n}$ & $\%$ \\
\hline Umur (th) & & \\
$2.0-2.9$ & 36 & 10,3 \\
$3.0-5.9$ & 88 & 25,4 \\
$6.0-8.9$ & 146 & 41,8 \\
$9.0-12.9$ & 79 & 22,5 \\
& & \\
Tempat Tinggal & 166 & 47,6 \\
Kota & 183 & 52,4 \\
Desa & & \\
& & \\
Jenis kelamin & 197 & 56,5 \\
Laki-laki & 152 & 43,5 \\
Perempuan & & \\
\end{tabular}

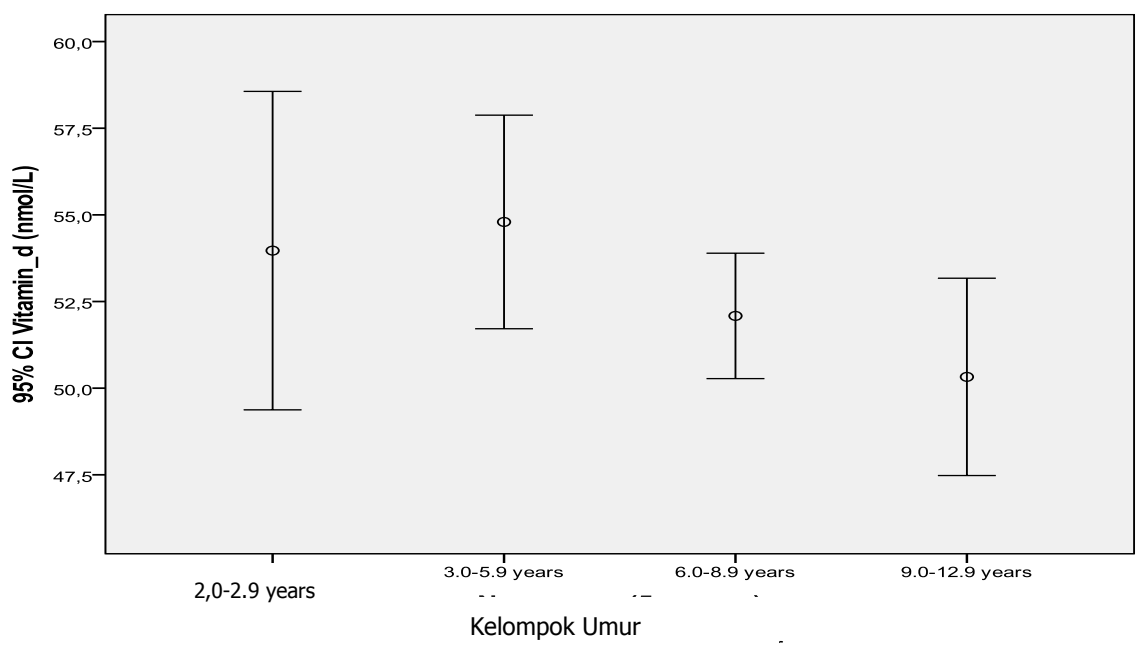

Gambar 1

Rerata kadar [25(OH)D] menurut kelompok umur. 
Tabel 2

Status Vitamin D menurut Jenis Kelamin dan Tempat Tinggal

\begin{tabular}{|c|c|c|c|c|c|c|c|c|c|c|}
\hline \multirow{3}{*}{ Status vitamin D } & \multirow{2}{*}{\multicolumn{2}{|c|}{ Jumlah }} & \multicolumn{4}{|c|}{ Jenis kelamin } & \multicolumn{4}{|c|}{ Tempat tinggal } \\
\hline & & & \multicolumn{2}{|c|}{ lelaki } & \multicolumn{2}{|c|}{ perempuan } & \multicolumn{2}{|c|}{ kota } & \multicolumn{2}{|c|}{ desa } \\
\hline & $\mathrm{n}$ & $\%$ & $n$ & $\%$ & $\mathrm{n}$ & $\%$ & $n$ & $\%$ & $n$ & $\%$ \\
\hline Deficiency & 0 & 0 & 71 & 0 & 0 & 0 & 0 & 0 & 0 & 0 \\
\hline Insufficiency & 158 & 45,1 & 114 & 35,7 & 87 & 57,2 & 75 & 45,5 & 82 & 45,1 \\
\hline Inadequate & 172 & 49,3 & 13 & 57,6 & 58 & 38,2 & 79 & 47,9 & 92 & 50,5 \\
\hline desireble & 20 & 5,6 & 198 & 6,6 & 7 & 4,7 & 11 & 6,7 & 8 & 4,4 \\
\hline Total & 350 & & 198 & & 152 & & 165 & & 182 & \\
\hline
\end{tabular}

Tabel 3

Status Vitamin D Partisipan

\begin{tabular}{lcccccc}
\hline \multirow{2}{*}{ Status vitamin D } & \multicolumn{3}{c}{ Jumlah } & \multicolumn{3}{c}{ Jenis kelamin anak } \\
\cline { 2 - 7 } & $\mathrm{n}$ & $\%$ & $\mathrm{n}$ & $\%$ & $\mathrm{n}$ & $\%$ \\
\hline Deficiency $(<25 \mathrm{nmol} / \mathrm{l})$ & 0 & 0 & 0 & 0 & 0 & 0 \\
Insufficient $(25-49 \mathrm{nmol} / \mathrm{l})$ & 157 & 45,1 & 71 & 35,7 & 87 & 57,2 \\
Inadequate $(50-74 \mathrm{nmol} / \mathrm{l})$ & 172 & 49,3 & 114 & 57,6 & 58 & 38,2 \\
Desirable $>=75 \mathrm{nmo} / / \mathrm{l})$ & 20 & 5,6 & 13 & 6,6 & 7 & 4,7 \\
Total & 350 & 100 & 198 & 100 & 152 & 100 \\
\hline
\end{tabular}

Tabel 4

Proporsi Status Vitamin D antar negara peserta SEANUTS (\%)

\begin{tabular}{lcccc}
\hline Status vitamin D & Indonesia & Malaysia & Thailand & Vietnam \\
\hline Deficient & 0 & 4,1 & 2 & 11,1 \\
Insufficient & 44,0 & 39,6 & 31,7 & 37,1 \\
Inadequate & 50,3 & 39,9 & 47,2 & 29,4 \\
Desirable & 5,6 & 16,3 & 19,2 & 22,4 \\
\hline
\end{tabular}

Tabel 5

Status Vitamin D menurut Tempat Tinggal

\begin{tabular}{lcccc}
\hline Tempat Tinggal & insufficient & inadequate & desirable & Total \\
\hline Kota & $75(45,5 \%)$ & $79(47,9 \%)$ & $11(6,7 \%)$ & $165(100 \%)$ \\
Desa & $82(45,1 \%)$ & $92(50,5 \%)$ & $8(4,4 \%)$ & $182(100,0 \%)$ \\
\hline Total & $157(45,2 \%)$ & $171(49,3 \%)$ & $19(5,5 \%)$ & $347(100 \%)$ \\
\hline
\end{tabular}




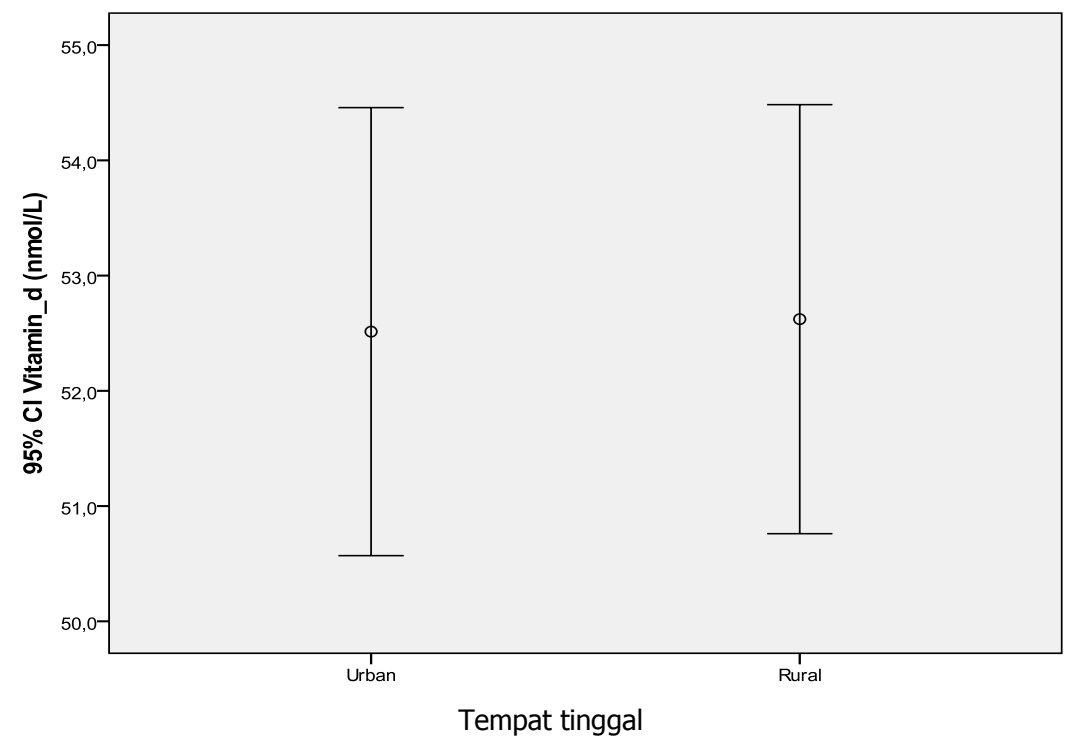

Gambar 2

Rerata Kadar Vitamin D menurut Tempat Tinggal

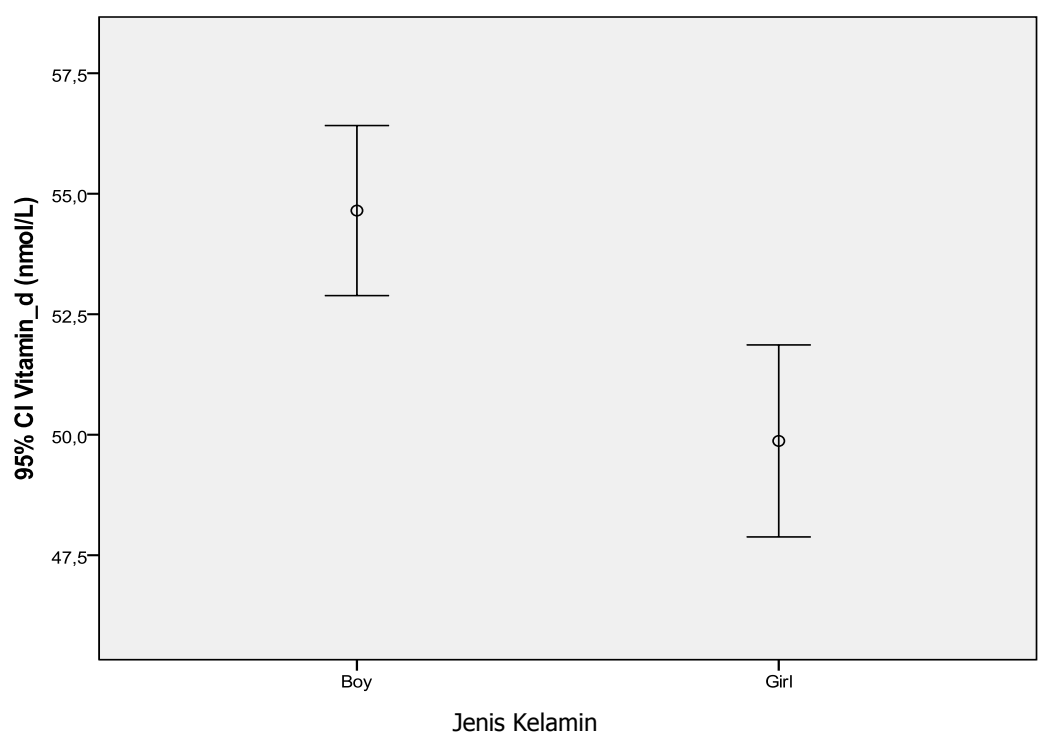

Gambar 3

Rerata Kadar Vitamin D menurut Jenis Kelamin

Menurut jenis kelamin anak laki-laki sebagian besar $(57,6 \%)$ mengalami inadequate, sedangkan anak perempuan sebagian besar $(57,2 \%)$ mengalami insufficient (Tabel 3$)$.

Dibandingkan antar negara nampak bahwa Anak Indonesia mempunyai status vitamin $D$ ([25(OH)D]) paling baik, karena tidak ditemukan anak dengan status kekurangan vitamin $D$ (deficient). Namun demikian proporsi status vitamin $D$ insufficient dan inadequate anak Indonesia paling besar dibandingkan dengan dengan anak Malaysia, Thailand dan Vietnam (Tabel 4). Proporsi status vitamin D antara anak yang tinggal di kota dan di desa hampir sama 
(Tabel 5). Gambar 2 menunjukkan bahwa kadar vitamin $D$ anak yang tinggal di kota maupun di desa tidak jauh berbeda.

Kadar vitamin D antara anak laki-laki dan perempuan sangat berbeda, anak laki-laki mempunyai rata-rata kadar vitamin $D$ lebih tinggi dibandingkan dengan rata-rata kadar vitamin D anak perempuan.(Gambar 3). Gambar 4 menjelaskan bahwa baik pada anak laki-laki maupun prempuan, penurunan kadar vitamin $\mathrm{D}$ dimulai pada saat anak umur 6 tahun ke atas. Gambar 5 menjelaskan tentang sebaran status vitamin $D$ pada beberapa kelompok umur anak. Terlihat dari gambar bahwa persentase anak yang mempunyai kadar vitamin $\mathrm{D}$ paling tinggi terdapat pada kelompok umur paling muda yaitu umur 2,0-2,9 tahun.

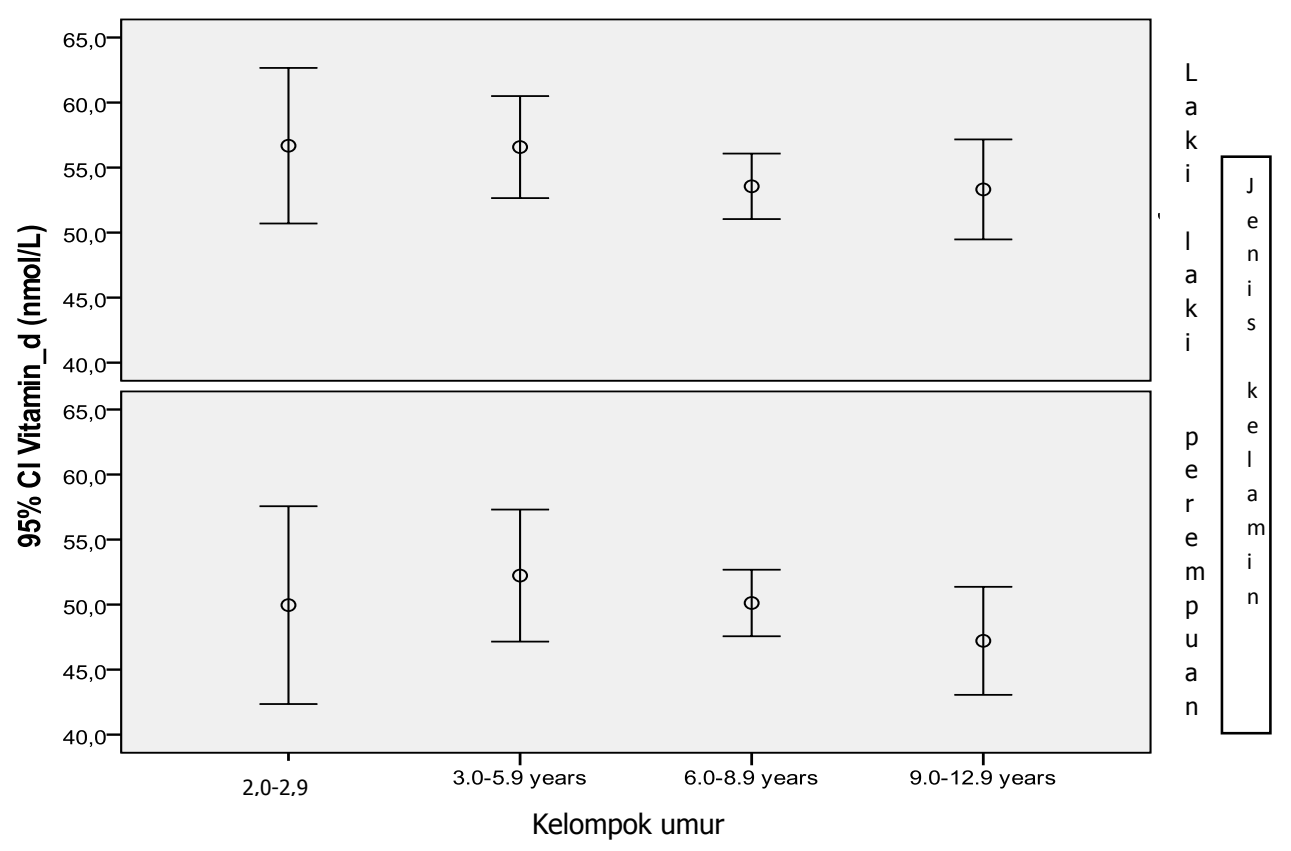

Gambar 4

Rerata Kadar Vitamin D menurut Kelompok Umur dan Jenis Kelamin

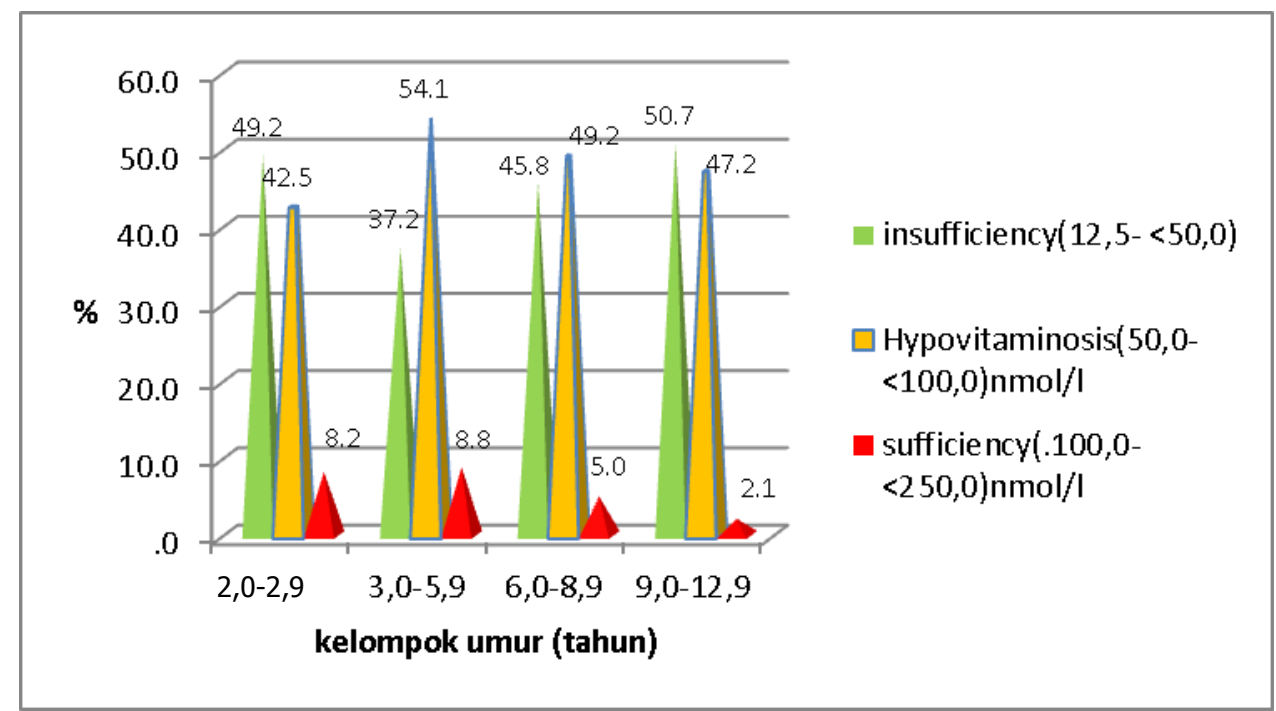

Gambar 5

Status Vitamin D menurut Kelompok Umur 


\section{BAHASAN}

Hasil penelitian di beberapa negara menunjukkan prevalensi insufficiency vitamin $D$ cukup tinggi, meskipun prevalensi kekurangan (deficiency) vitamin $D$ belum banyak muncul $1,2,3,4$, dan bahkan sekarang cenderung meningkat ${ }^{7}$. Temuan ini sejalan dengan hasil penelitian ini dimana tidak ditemukan anak umur 2,0-12,9 tahun dengan status kekurangan vitamin $D$, namun sudah ada anak dengan status insufficient $(45,1 \%)$ dan inadequate $(49,3 \%)$. Batasan status vitamin D yang digunakan dalam artikel ini sebagai berikut deficiency vitamin $\mathrm{D}$ apabila kadar vitamin $\mathrm{D}$ serum $(25(\mathrm{OH}) \mathrm{D})<25 \mathrm{nmol} / \mathrm{L}$, insufficiecy bila kadar vitamin $D$ antara 25-49 nmol/L, inadequate bila kadar vitamin $\mathrm{D}$ antara $50-74$ $\mathrm{nmol} / \mathrm{L}$, dan dinyatakan status desirable bila kadar vitamin $D \geq 75 \mathrm{nmol} / \mathrm{L}^{4}$. Temuan penelitian, secara umum kadar vitamin $D$ anak umur dibawah 5 tahun lebih tinggi dibandingkan anak yang berumur lebih tua ( $>6$ tahun), secara rinci pada anak kelompok umur 2,0-2,9 tahun mempunyai kadar vitamin D 54,0 $\pm 2,3$ $\mathrm{nmol} / /$, sedangkan pada anak kelompok umur 9,0-12,9 tahun kadar vitamin D 50,3 $\pm 1,4$ $\mathrm{nmol} / \mathrm{l}$. Adapun status vitamin $\mathrm{D}$ anak usia 2,012,9 tahun adalah sebagai berikut tidak dijumpai (0 persen) anak dengan deficiency vitamin $D$, anak dengan status insufficiency sebesar 45,1persen, status inadequate sebesar 49,3 persen, dan dengan status vitamin $D$ cukup hanya 5,6 persen. Dari temuan penelitian ini dapat dikatakan bahwa kadar vitamin $D$ anak anak umur 2,0 - 12,9 tahun dalam keadaan tidak mencukupi untuk memenuhi kebutukan optimal, keadaan ini apabila terus berlanjut tidak memungkinkan akan menjadi keadaan yang mengkhawatirkan yaitu terjadinya keadaan anak kekurangan vitamin D. Apabila status kekurangan vitamin $D$ terjadi dapat mengakibatkan timbulnya kelainan bentuk tulang seperti rickets yang banyak terjadi pada kelompok anak anak dan osteomalacia pada orang dewasa.

Vitamin D mempunyai peran penting dalam penyerapan kalsium dan mencegah rickets dan osteomalacia. Hasil penelitian menunjukkan bahwa kadar vitamin $D$ yang rendah dalam darah berhubungan dengan meningkatnya osteomalacia ${ }^{2}$. Peran vitamin $D$ selain memperkuat fungsi tulang, akhir-akhir ini telah banyak ditemukan perananan vitamin $\mathrm{D}$ dengan kejadian kanker terutama kanker usus, dan dengan kadar vitamin $D$ yang rendah memicu kematian karena kanker ${ }^{5}$. Selain itu ditemukan bukti bahwa hubungan status vitamin $D$ dengan penyakit jantung dan kegemukan ${ }^{6}$. Hasil penelitian ini mendapati kadar vitamin $D$ anak mulai menurun pada umur lebih dari 6 tahun, dan hal ini ditemukan pada anak laki-laki maupun pada anak perempuan. Temuan ini menunjukkan bahwa paparan sinar matahari merupakan sumber utama vitamin $D$, karena anak usia 6 tahun keatas sudah mulai memasuki usia sekolah dengan demikian kesempatan mereka bermain dibawah sinar matahari mulai berkurang. Ketika sinar ultraviolet dari sinar matahari masuk ke kulit, 7dehydrocholesterol di membran plasma berubah menjadi previtamin D3 di kulit ${ }^{11}$. Selain itu, penyebab dari tidak cukupnya vitamin D tersebut adalah rendahnya kandungan vitamin D pada makanan yang dikonsumsi. Jajanan anak sekolah adalah makanan ringan yang rendah kandungan nilai gizinya.

Hasil penelitian secara rinci kadar vitamin D menurut jenis kelamin menunjukkan anak lakilaki mempunyai kadar vitamin D $(54,7 \pm 0,9$ $\mathrm{nmol} / \mathrm{L}$ ) lebih tinggi dibandingkan kadar vitamin D anak perempuan $(49,9 \pm 1,0 \mathrm{nmol} / \mathrm{L})$, dan perbedaan ini cukup bermakna $(p<0,05)$. Seperti telah dijelaskan pada alinea sebelumnya bahwa sumber utama vitamin $D$ adalah dari paparan sinar matahari. Anak lakilaki lebih banyak main diluar rumah dibandingkan anak perempuan, sehingga anak laki-laki mempunyai kadar vitamin D lebih banyak. Vitamin $\mathrm{D}$ tidak hanya dapat dipenuhi dari makanan tetapi pemenuhan yang lebih efektif dari paparan sinar matahari, karena di dalam lapisan kulit manusia mengandung vitamin $D$ yang belum aktif dan dengan ultraviolet dari sinar matahari dapat berubah menjadi vitamin $\mathrm{D}$ aktif. Keadaan ini didukung dengan hasil penelitian yang menemukan adanya hubungan positif antara lama bermain diluar rumah dengan kadar vitamin $D(r=0,164$, $p=0,012$ ), namun kadar vitamin $D$ anak yang tinggal di kota $(52,5 \mathrm{nmol} / \mathrm{l})$ tidak berbeda dengan anak yang tinggal di desa $(52,6 \mathrm{nmol} / \mathrm{l})$.

Pengukuran vitamin $D$ yang digunakan pada penelitian ini adalah serum $25(\mathrm{OH}) \mathrm{D}$. Serum $25(\mathrm{OH})$ D merupakan marker paling akurat untuk mendeteksi status vitamin $\mathrm{D}$ pada 
manusia, akan tetapi pengukuran ini bukan tidak memiliki keterbatasan ketika digunakan untuk penelitian berbasis masyarakat. Hal ini karena serum 25(OH)D kurang tepat untuk digunakan menentukan status vitamin $D$ individu sepanjang tahun karena serum 25(OH)D ini bervariasi menurut cuaca, konsentrasi paling tinggi pada musim panas dan rendah pada musim spring. ${ }^{10}$ Akan tetapi untuk negara tropis seperti di Indonesia, pengukuran vitamin dengan serum 25(OH)D dapat diminimalisir pengaruh dari cuaca/ iklim. Serum $25(\mathrm{OH}) \mathrm{D}$ paling sesuai untuk diagnosis kekurangan vitamin $D$ dan untuk mngukur status vitamin D. Disisi lain, serum 1,25(OH)2D kurang sesuai digunakan untuk mengukur status vitamin D karena kadar serum $1,25(\mathrm{OH}) 2 \mathrm{D}$ sangat dipengaruhi oleh hormonal seperti parathyroid hormon (PTH) ${ }^{12}$.

\section{SIMPULAN DAN SARAN}

\section{Simpulan}

Kadar vitamin D-pada anak kelompok umur 2,02,9 tahun yaitu $54,0 \pm 2,3 \mathrm{nmol} / /$, sedangkan pada anak kelompok umur 9,0-12,9 tahun yaitu 50,3 $\pm 1,4$ $\mathrm{nmol} / \mathrm{l}$. Kadar vitamin $\mathrm{D}$ anak yang tinggal di kota $(52,5 \mathrm{nmol} / \mathrm{l})$ tidak berbeda dengan anak yang tinggal di desa $(52,6 \mathrm{nmol} / \mathrm{l})$. Pada anak laki-laki maupun perempuan, penurunan kadar vitamin $D$ dimulai pada saat anak umur 6 tahun ke atas. Terlihat pula bahwa persentase anak yang mempunyai kadar vitamin $D$ paling tinggi terdapat pada kelompok umur paling muda yaitu umur 2,0-2,9 tahun

\section{Saran}

Hasil penelitian menunjukkan bahwa status vitamin D pada anak usia 2-12,9 perlu mendapat perhatian meskipun diantara negara ASEAN, Indonesia persentase anak yang deficient belum terlihat tetapi presentase anak Indonesia yang insufficient dan inadequate paling tinggi sehingga perlu mendapat perhatian dari pemerintah untuk mencegah terjadinya ledakan deficient vitamin $D$ pada anak anak Indonesia khususnya pada anak usia 6-12 tahun

\section{RUJUKAN}

1. Holick MF, Chen TC, Lu Z, Sauter E. Vitamin $D$ and skin physiology: a D-lightful story. J Bone Miner Res. 2007;22 (Suppl 2):S28-3S3

2. Holick MF. Vitamin D deficiency. N Engl J Med. 2007:357:266-281.

3. Holick MF: High prevalence of vitamin D inadequacy and implications for health. Mayo Clin Proc. 2006;81:353-373.

4. Medical Advisory Secretariat, Ontario Health Technol. Micronutrient Forum Global Conference. 6-8 Juni 2014.

5. Chapuy MC, Preziosi $P$, Maamer $M$, Arnaud S, Galan P, Hercberg S, et al. Prevalence of vitamin $D$ insufficiency in an adult normal population. Osteoporos Int 1997;7:439-443.

6. Buttigliero $C$, Monagheddu $C$, Petroni $P$, Saini A, Dogliotti L, Ciccone G, et al "Prognostic role of vitamin $d$ status and efficacy of vitamin $d$ supplementation in cancer patients: a systematic review". The Oncologist 2011;16:1215-27.

7. Wang TJ, Pencina MJ, Booth SL, Jacques $\mathrm{PF}$, Ingelsson $\mathrm{E}$, Lanier $\mathrm{K}$, et al. Vitamin D deficiency and risk of cardiovascular disease. Circulation. 2008;117:503-11.

8. Looker AC, Pfeiffer CM, Lacher DA, Schleicher RL, Picciano MF, Yetley EA. Serum 25-hydroxyvitaminDstatus of the US population: 1988-1994 compared to 20002004. Am J Clin Nutr. 2008;88(6):15191527.

9. Soesanti $F$, Pulungan A, Tridjaja B, Batubara JRL. Vitamin D profile in healthy children aged 7-12 years old in Indonesia.Int J Pediatr Endocrinol. 2013,(Suppl 1):167-171

10. Zerwekh JE. Blood biomarkers of vitamin D status. $\quad A m \quad J \quad C l i n$ Nutr.2008;87(suppl):1087S-91S.

11. Holick MF. Vitamin D and Sunlight: Strategies for Cancer Prevention and Other Health Benefits. Clin J Am Soc Nephrol. 2008; 3: 1548-1554.

12. Lips Paul. Review Relative Value of 25(OH)D and 1,25(OH)2D Measurements. Journal of Bone and mineral Research. 2007;22(11).1668-1671. 